\title{
Development of a nursing diagnosis educational software program
}

\author{
Desenvolvimento de um software educativo de diagnósticos de enfermagem \\ Desarrollo de un software educativo para diagnosticos de enfermeria
}

\author{
Miriam de Abreu Almeida ${ }^{a}$ \\ Amália de Fátima Lucena $a^{a, b}$ \\ Aline Tsuma Gaedke Nomura ${ }^{\mathrm{a}, \mathrm{c}}$ \\ Murilo Graeff ${ }^{a, d}$ \\ Natália Chies ${ }^{\mathrm{e}}$ \\ Lisiane Pruinellif
}

How to cite this article: Almeida MA, Lucena AF, Nomura ATG, Graeff M, Chies N, Pruinelli L. Development of a nursing diagnosis educationa software program. Rev Gaúcha Enferm. 2021;42:e20190283. doi: https://doi. org/10.1590/1983-1447.2021.20190283
Universidade Federal do Rio Grande do Sul (UFRGS), Escola de Enfermagem. Programa de Pós-Graduação em Enfermagem. Porto Alegre, Rio Grande do Sul, Brasil.

${ }^{\natural}$ Hospital de Clínicas de Porto Alegre (HCPA), Comissão do Processo de Enfermagem. Porto Alegre, Rio Grande do Sul, Brasil.

Hospital de Clínicas de Porto Alegre (HCPA), Unidade de Radiologia. Porto Alegre, Rio Grande do Sul, Brasil.

Hospital Divina Providência. Porto Alegre, Rio Grande do Sul, Brasil.

- Universidade Federal do Rio Grande do Sul (UFRGS), Escola de Enfermagem. Porto Alegre, Rio Grande do Sul, Brasil.

University of Minnesota, School of Nursing \& Institute for Health Informatics. Minneapolis, Minnesota, United States of America.

\section{ABSTRACT}

Introduction: The human-computer interaction is essential in simulated electronic systems associated with teaching-learning activities. Interactive clinical cases reinforce the diagnostic reasoning ability, a stage of the advanced Nursing Process.

Purpose: To build educational software, based on NANDA International, to improve the accuracy of nursing diagnoses.

Method: Methodological study in three stages: preparation and validation of case studies; construction; homologation and evaluation. Held between January / 2012 and December / 2013, in a university hospital in southern Brazil. Teachers, nurses, undergraduate students and graduate students in nursing and information technology participated. Approved by the Research Ethics Committee (130035).

Results: Construction of five case studies and two versions of the software: one simulates the reasoning process for establishing the diagnosis; another, aimed at teachers, makes it possible to edit/create cases.

Conclusion: The software helps in the teaching-learning process, generating accurate diagnoses, supporting more appropriate interventions

Keywords: Software. Nursing diagnosis. Education. Nursing informatics.

\section{RESUMO}

Introdução: A interface humano-técnica é essencial em sistemas eletrônicos simulados associados a atividades de ensinoaprendizagem. Casos clínicos interativos reforçam a habilidade de raciocínio diagnóstico, etapa do Processo de Enfermagem avançado. Objetivo: Construir um software educativo, baseado na NANDA International, para melhoria da acurácia de diagnósticos de enfermagem.

Método: Estudo metodológico em três fases: elaboração e validação de estudos de caso; construção; homologação e avaliação. Realizado entre janeiro/2012 e julho/205, em hospital universitário do sul do Brasil. Participaram professores, enfermeiros, alunos de graduação e alunos de pós-graduação de enfermagem e tecnologia da informação. Aprovado pelo Comitê de Ética em Pesquisa (130035).

Resultados: Construção de cinco estudos de caso e duas versões do software: uma simula o processo de raciocínio para estabelecimento do diagnóstico; outra, destinada a professores, possibilita editar/criar os casos.

Conclusão: 0 software auxilia no processo de ensino-aprendizagem gerando diagnósticos acurados, subsidiando intervenções mais adequadas.

Palavras-chave: Software. Diagnóstico de enfermagem. Educação. Informática em enfermagem.

\section{RESUMEN}

Introducción: Interfazhumano-técnica es esencial en sistemas electrónicos simulados asociados con actividades deenseñanza-aprendizaje. Los casos clínicos interactivos refuerzan la capacidad de razonamiento diagnóstico, una etapa del proceso avanzado de enfermería.

Objetivo: Construir un software educativo, basado en NANDA International, para mejorar la precisión de los diagnósticos de enfermería.

Método: Estudio metodológico en tres fases: preparación y validación de estudios de caso; construcción; homologación y evaluación. Celebrada entre enero/2012 y diciembre/2013, en hospital universitario en el sur de Brasil. Participaron docentes, enfermeras, estudiantes universitarios y estudiantes de posgrado en enfermería y tecnología de la información. Aprobado por el Comité de Ética de Investigación (130035).

Resultados: Construcción de cinco estudios de caso y dos versiones del software: uno simula el proceso de razonamiento para establecer el diagnóstico; otro, dirigido a docentes, permite editar/crear casos.

Conclusión: El software ayuda en el proceso de enseñanza-aprendizaje, genera diagnósticos precisos y respalda intervenciones más apropiadas.

Palabras clave: Programas informáticos. Diagnóstico de enfermería. Educación. Informática aplicada a la enfermería. 


\section{INTRODUCTION}

One of the global priorities in the use of health technology is information and communication technology in nursing ${ }^{(1)}$. Its use has been growing rapidly in order to improve patient safety, organizational efficiency and speed of monitoring ${ }^{(2)}$. These activities require dynamism and creativity and, when combined with the nursing classification systems, they are excellent tools that facilitate the application of the Nursing Process (NP), improve and provide visibility to health records, which is fundamental in strengthening the science of nursing. profession ${ }^{(3)}$.

From the nursing terminologies, highlighting the taxonomy of Nursing Diagnostics (NDs) from NANDA International Inc. (NANDA-I), it is possible to interpret human responses, guiding the selection of appropriate interventions for different clinical cases. This diagnostic reasoning process, although fundamental, is fragile in its application and learning, suggesting a technical-scientific lack of preparation by professionals ${ }^{(4)}$. Thus, tools are needed to stimulate clinical reasoning and critical thinking skills, supporting practice and $N P^{(3-4)}$.

Although technological resources are advantageous in care and care management, a literature review study points to gaps in scientific production on the topic $\mathrm{c}^{(5)}$. The same research shows, in particular, the scarcity in the production of educational software to improve the performance of the nursing team in the hospital environment $t^{(5)}$.

Alternatively, the use of interactive clinical case simulations contributes to the development of diagnostic reasoning skills and, consequently, to their accuracy ${ }^{(3,6-8)}$. Some studies have been conducted with clinical cases as a source of learning, based on the Problem-Based Learning (PBL) methodology, which seems to provide better effectiveness in teaching and student performance ${ }^{(9)}$. Furthermore, PBL with clinical cases presents itself as an alternative to assist in the teaching-learning challenges identified, not only among nursing students, but also in the continuing education processes of nurses ${ }^{(8)}$.

In this sense, the human-technical interface (HTI) is an extremely important dimension to be considered, both in terms of implementing a simulated electronic system and in the generation of teaching-learning activities that reinforce the diagnostic reasoning ability, a fundamental stage of advanced $N P^{(8,10)}$. Derived from the field of psychology and computer and social sciences, HTI is focused on understanding how humans interact with technology, both in systems and devices, and how to make this interaction as valuable as possible ${ }^{(11)}$. However, the appropriation of software process models by nurses is still incipient, which highlights the need for further study of nursing in this theme $e^{(11)}$.

Thus, in order to bring nursing closer to theoretical and methodological frameworks for software development and to supply the lack of tools to guide nurses' diagnostic reasoning process, this research aimed to build educational software to improve accuracy in establishing NDs.

\section{METHOD}

A methodological study that aims to develop instruments, which may involve complex and sophisticated methods, including the development, validation and evaluation of research tools and methods ${ }^{(12)}$. The study was carried out in a university hospital in the south of Brazil, with the participation of professors, nurses and graduate students in the fields of nursing and information technology.

The project was developed in three stages: preparation and validation of case studies; construction of educational software for the accurate establishment of NDs; and approval and evaluation of the Software. The steps are described in Figure 1.

\section{Preparation and validation of case studies}

In this first phase, a working group was formed with three nursing professors, three nursing assistants, three nursing students and a computer science professional, totaling ten participants. The case studies were constructed considering different levels of complexity according to the guidelines for the development of written case studies ${ }^{(13)}$. The criteria for diagnostic precision/accuracy were established using the Nursing Diagnostic Accuracy Scale-Version 2 (EADE-Version 2) ${ }^{(14)}$. The consensus of four experts ${ }^{(13)}$ chosen for convenience was used to validate the studies. The inclusion criteria were as follows: being a nurse with at least five years' clinical experience and knowledge of NDs, according to the NANDA-I taxonomy and electronic health records, all members of the permanent institutional committee that studies NP. The participants received a letter of guidance for the preparation and refinement of the studies, and data were requested to characterize the sample.

The experts analyzed the adequacy of the defining characteristics, related factors and risk factors. The analyzes focused on the quality of the studies. For this, they observed the specifics, clarity, level of precision and whether the diagnostic reasoning process was adequate. The instrument also assessed the degree of difficulty of the studies as easy, medium, or difficult. The data were analyzed considering the consensus among experts, using the NANDA-I framework ${ }^{(15)}$.

\section{Software construction}

The Incremental Development methodology was used in the second phase of the study. It is a staged planning 


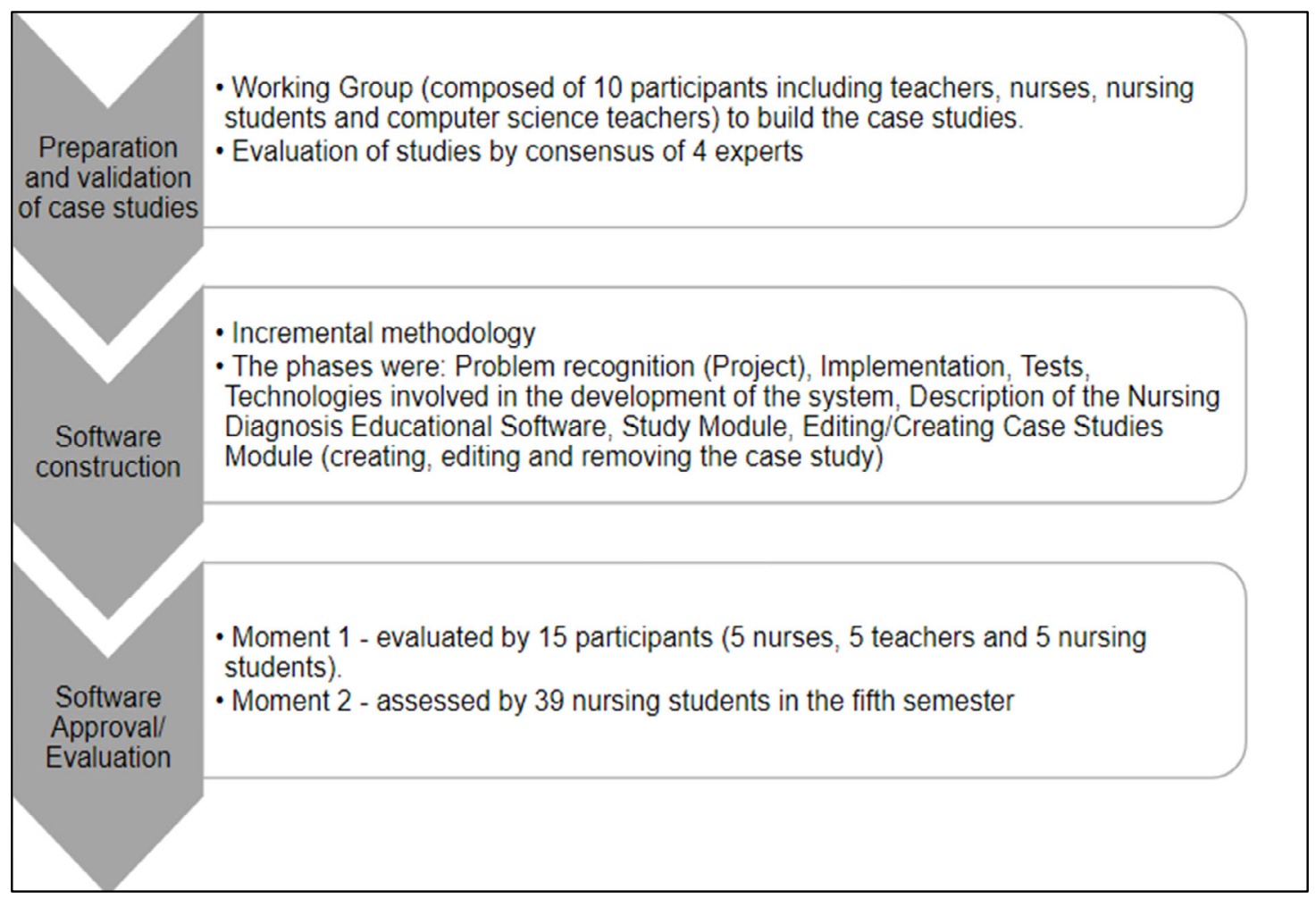

Figure 1 - Study steps

Source: The authors, 2015.

strategy in which several parts of the system are developed in parallel and integrated when complete, with the possibility of each step being later revised for modifications and increments. This approach is based on the "System Life Cycle" theory, a process composed of phases through which the system moves from planning to re-planning ${ }^{(16)}$. Because it is interactive, the incremental model quickly produces operational versions of the software ${ }^{(16)}$. In this research, the phases were sectioned in recognition of the problem (project), Implementation; tests, technologies involved in the development of the system, description of the Nursing Diagnosis Educational Software, Study Module, Editing/Creating Case Studies Module (creating, editing and removing case studies).

During the problem recognition phase (project), state, behavior and use diagrams were built, according to the technical specifications suggested by the software developer, in addition to the definition of deadlines for carrying out the activities necessary for the implementation of the project ${ }^{(16)}$.

The design and creation of the screens that would make up the software were started in the implementation phase. Then, the logical structure of the program was inserted, followed by the integration of these parts and, finally, modular test ${ }^{(16)}$. It should be noted that these steps were performed repeatedly until the needs and requirements of the software were reached.
In the testing phase, the system was subjected to acceptance and quality control experiments. The tests were carried out by a team of professors, nurses and Master's students. The developer made adjustments according to the needs identified by the tests.

The software was developed using .NET technology (Microsoft) in the Visual Basic programming language, in the Visual Studio 2008 development environment, which was run on the Windows Operating System.

For the software description phase, two versions were developed - one for students and another for teachers.

The main module of the software, the Study Module, aims to present each step of the diagnostic reasoning, while the Editing/Creating Case Studies Module, present in the version for teachers, is intended to perform three main operations in the case studies: creation, editing and removal.

\section{Software Approval/Evaluation}

The third stage took place in two phases: initially, an evaluation was carried out with fifteen participants selected by convenience (five nurses, five university professors and five nursing students). Then, the evaluation was carried out by 39 nursing students in the fifth semester. The software was made available to the participants, along with an evaluation 
form on the following topics: content of the case studies, usability of the software and didactics on learning the cases. Each participant was instructed to conduct one of the studies.

As for the content of the case studies and usability of the software, the items evaluated were: ease of use, contains clear instructions, visually attractive, interactive. In relation to didactics, the following items were evaluated: reinforces concepts progressively, need for help from literature to develop the stages, the number of evidences was sufficient to select the NDs, would recommend using the software. In addition, each item should be assessed based on the following degrees of relevance: strongly agree, agree, no opinion, disagree and strongly disagree.

The subjects signed the Free and Informed Consent Form. The Project was approved by the Institution's Research Ethics Committee (\# 130035).

\section{Q RESULTS}

The results showed the three phases of the research: the first describes how the case studies were elaborated, then the details of the software construction and, finally, the approval/evaluation of the software.

\section{Preparation and validation of case studies}

The five case studies developed addressed: child with neoplasm, elderly in clinical care, elderly in critical care, adult with mental disorder and woman in gestational period.

The four specialists had an average of 16 years since graduation, one of them with publications on the theme, and all were members of the group responsible for managing the NP in the field of study. The quality of the five case studies was evaluated positively, considering the following criteria: whether the cases represent typical clinical practice situations, if the text has clear wording, whether the studies reflect different clinical situations, intellectual capacities similar to those used in a real clinical setting are required, considers diagnoses at various levels of accuracy. As for the assessment of the difficulty, two studies were considered easy, one of medium level and two difficult.

Based on the clinical reasoning of the specialists and the evaluations of the items above, it was possible to refine the studies in order to make them more intelligible and faithful to clinical practice. NDs not selected by specialists were excluded, and the case studies were remodeled.

\section{Construction of educational software for the accurate establishment of nursing diagnoses}

The case studies comprised the patient's clinical history, list of relevant data and different clusters of data that led to different diagnostic hypotheses. Relevant data includes defining characteristics, related factors and risk factors for possible diagnoses. If the data grouping leads to a ND focused on the problem, syndrome or health promotion, it would be directed to a next step, for the selection of a related factor. If the ND were at risk, it would automatically advance to the diagnosis selection screen, since the risk factors would have already been selected in the previous step as relevant data. Each step of this process was distributed on one or more screens that made it possible to migrate to the next one in case of a hit. If the chosen answer was not correct, the system gave instructions to return to the previous step, allowing a new selection. The case study is completed when all groupings have been completed. The user will then be able to review the diagnosis statement for each data set before finalizing.

Two versions were built, one for students and one for teachers. The first contains the main software module, called the Study Module (Figure 2), which simulates the performance of a ND based on the case study.

The teacher version contains the Study Module and the Case Study Edition/Creation Module integrated in the same flowchart (Figure 3).

The Study Editing/Creation Module also offers the possibility to import/add to the list a new study made available by the teacher.

Didactic screens were developed (Figure 4) in the Study Module, where the objective of the software, the instructions for solving an exercise and the important definitions referring to the present terminology are presented. Afterwards, a list of case studies that can be exercised is displayed.

The Editing Module allows you to create new case studies, in addition to editing and removing old ones. Thus, in the Study Creation option it is possible to create countless studies in the same pattern as the studies elaborated during the project and that become part of the software. The creation process begins with the description of the patient's history and follows each step as described in the Study Module. Upon completion and saving the study, a file is generated that can be made available to students.

In the Study Edition operation, in addition to creating a new study, the teacher can edit an original study, or a previously created study, in case it is necessary to correct or add information. The editing process is analogous to the creation process, with the same screens for each stage. When saving, a file is generated that can be made available to students. If the student has the old study on his computer, it will be automatically updated once the new one is added.

In addition, when selecting the Case Study Removal option, the list with available studies and another list with those excluded is displayed. An available study can be deleted and later restored. Those that are excluded are not available in the Study Module. 


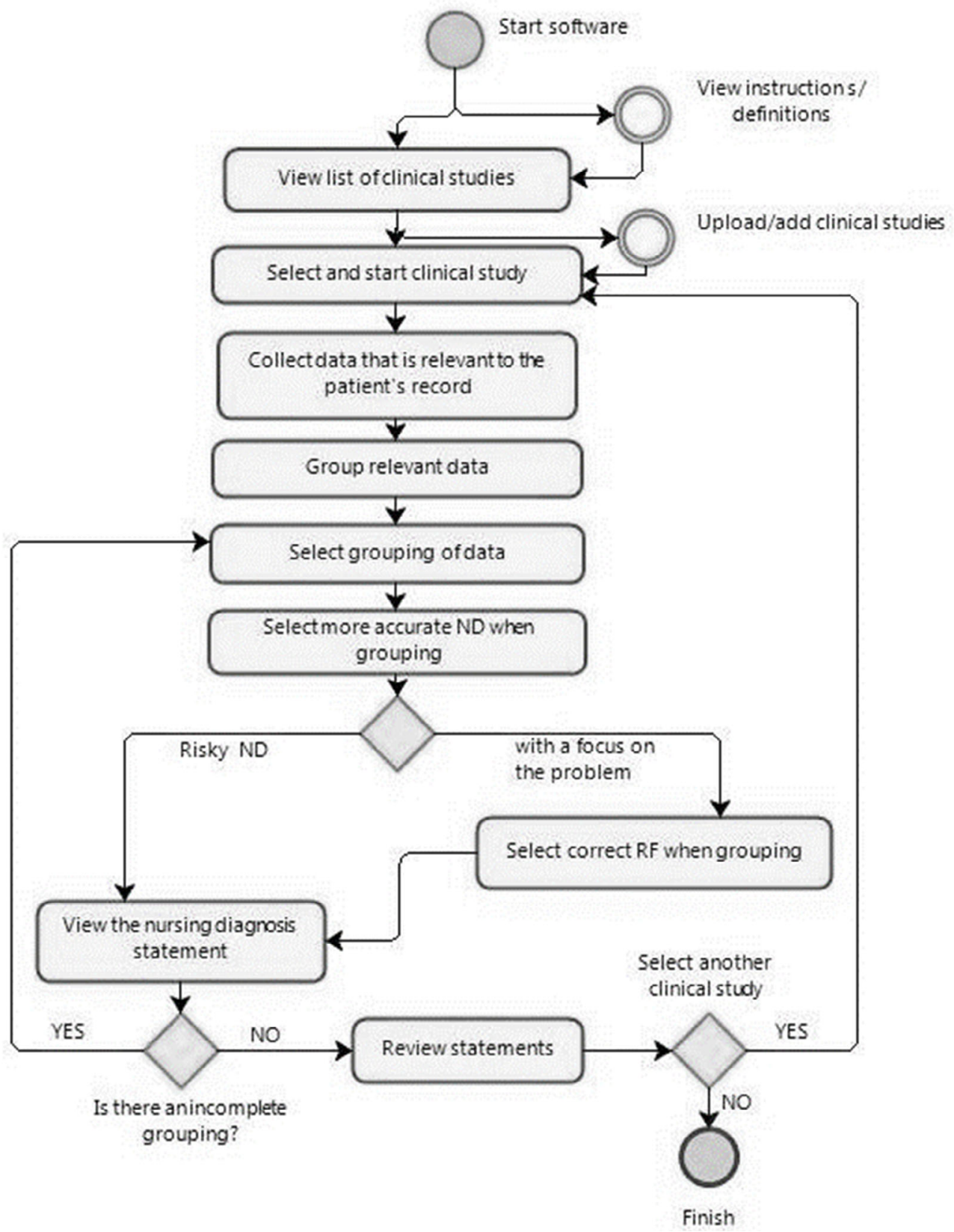

Figure 2 - Study Module

Source: The authors, 2015

With the proposed approach to the development of this educational software, it is possible to keep the software always up to date in a dynamic and real-time interaction by simulating the reality experienced through case studies, thus optimizing teaching-learning.

\section{Software Approval/Evaluation}

In addition to the evaluation of the case studies, presented in item 3.1, the software was evaluated for tool usability. In the evaluation of students, according to table 1 - considering the answers "fully agree" and "agree"- the studies were assessed as relevant and the data were clearly written for $97.44 \%$, and only one student considered that the studies did not contribute to increase their knowledge. As for usability assessment, 100\% of students agreed that the software is easy to use.

The software was rated as being self-explanatory, interactive and useful for learning. Some suggestions for improvements in the instructions for certain steps have been considered and implemented in order to make the software more effective. 


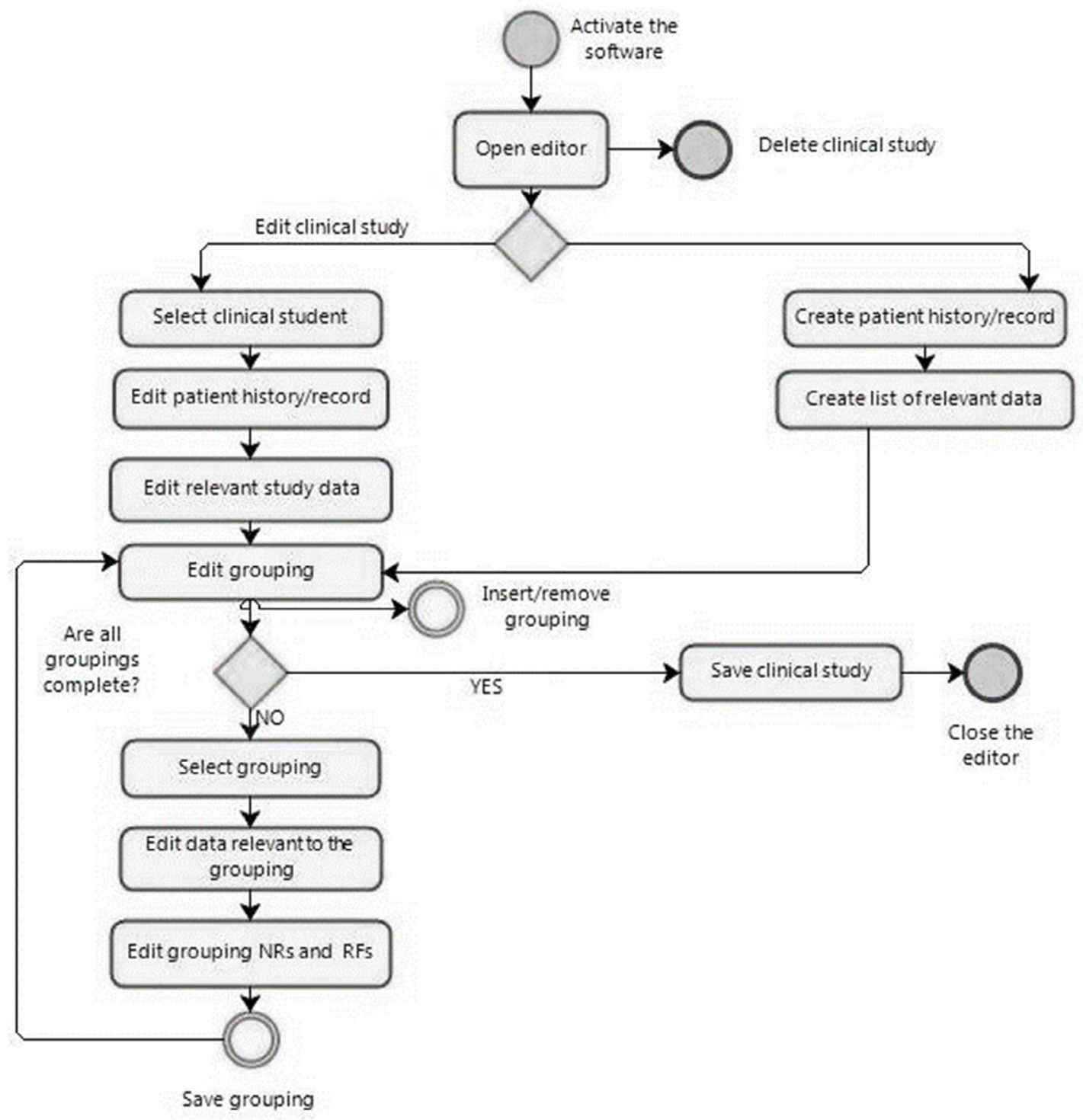

Figure 3 - Case Study Editing/Creation Module Source: The authors, 2015.

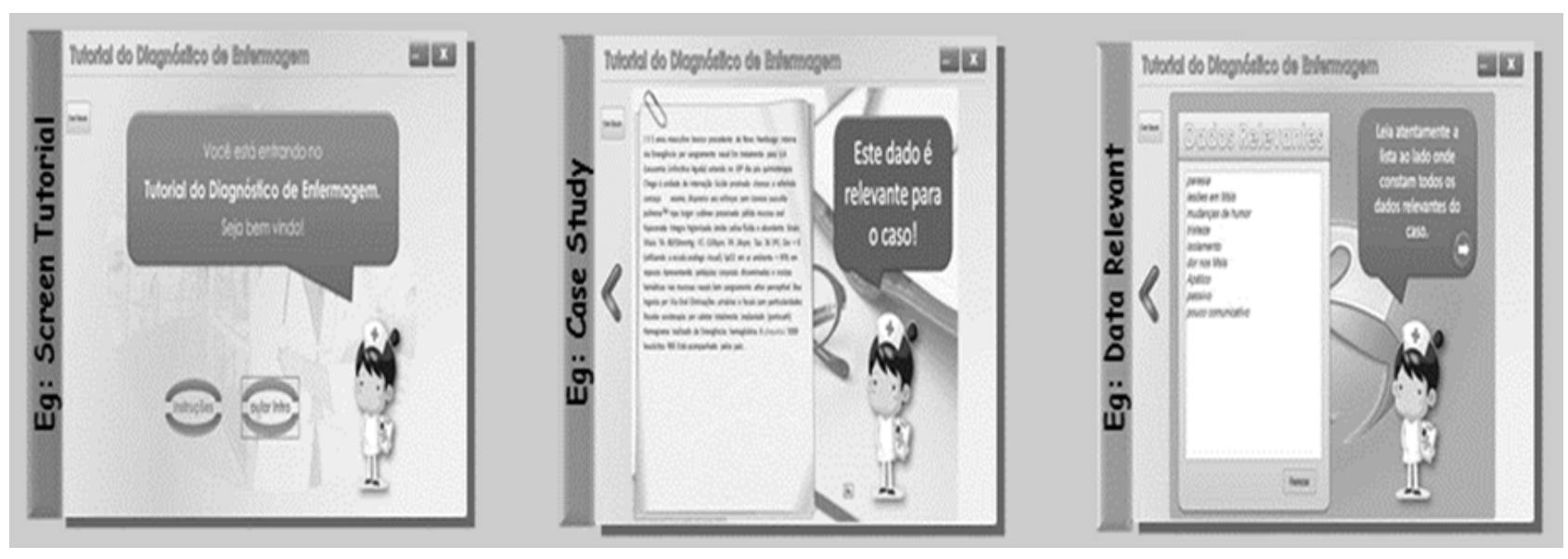

Figure 4 - Didactic screens built for software development Source: Prepared by the authors, 2015. 
Table 1 - Software approval

\begin{tabular}{lllll} 
Variables & \multicolumn{5}{c}{$\mathbf{n}(\%)$} & CA \\
Content (from the case studies) & CA & NO & D & CD \\
It was written in a clear and concise manner & $27(69.23)$ & $11(28.21)$ & $1(2.56)$ & \\
It is relevant & $29(74.36)$ & $9(23.08)$ & $1(2.56)$ & \\
Provides accurate information & $23(58.97)$ & $15(38.46)$ & $1(2.56)$ & \\
It includes appropriate amount of data & $24(61.54)$ & $15(38.46)$ & & $1(2.56)$ \\
$\begin{array}{l}\text { Have you expanded your knowledge about the } \\
\text { elaboration of the nursing diagnosis? }\end{array}$ & $25(64.10)$ & $13(33.33)$ & &
\end{tabular}

\section{Usability (of Software)}

\begin{tabular}{lllll}
\hline It is easy to use & $29(74.36)$ & $10(25.64)$ & & \\
Has clear instructions & $27(69.23)$ & $10(25.64)$ & & 2(5.13) \\
It is motivating & $25(64.10)$ & $12(30.77)$ & $1(2.56)$ & $1(2.56)$ \\
Visually attracted & $29(74.36)$ & $9(23.08)$ & $1(2.56)$ & \\
It is interactive & $27(69.23)$ & $9(23.08)$ & $3(7.69)$
\end{tabular}

\section{Didactics}

Enhances content progressively

Did the materials promote learning?

Did you need help from the literature to develop the steps?

Has the level of evidence to define the choice of the priority nursing diagnosis facilitated choice?

If this Software provided more case studies, would you like to do them?

$\begin{array}{lllll}24(61.54) & 15(38.46) & & & \\ 26(66.67) & 9(23.08) & 2(5.13) & 2(5.13) & \\ 10(25.64) & 7(17.95) & 1(2.56) & 11(28.21) & 10(25.64) \\ 26(66.67) & 11(28.21) & & 2(5.13) \\ 36(92.31) & 2(5.13) & & \end{array}$

Source: The authors, 2015

Note: Completely Agree (CA), Agree (A), No opinion (NO), Disagree (D) e Completely Desagree (CD)

The Educational Software for Nursing Diagnosis ${ }^{\circledR}$ was registered at the National Institute of Industrial Property (INPI)(17) under registration BR 512014 001195-0.

\section{DISCUSSION}

The creation of the Software arose from the demand for diversified strategies to train new nurses admitted to a referral hospital with a computerized NP, and to encourage students to develop clinical reasoning and critical judgment in future professional practice. Considering the dynamics between university and hospital practice, there was a need to develop a method that would favor the improvement of diagnostic accuracy, considered a challenge in daily practice. In this sense, it is understood that the software created corroborates the following results in the teaching-learning process: minimizing failures in diagnostic choices, updating nurses in clinical practice, use of software as a complementary tool with a formative character in undergraduate courses, pointed out as an excellent strategy for the development of diagnostic skills ${ }^{(9)}$. 
The software development followed the software specification steps in accordance with the HTI requirements ${ }^{(18)}$, aiming to supply the learning needs. In addition, the five case studies were evaluated by experts who had extensive knowledge of the NP and the NANDA-I taxonomy. The studies were developed considering the dynamics of the software to be built, in order to enable the participant's performance and interactivity as a didactic strategy $y^{(6)}$. The intention was to associate the use of technology with case studies to stimulate the development of skills in students in training, as well as in the instrumentalization of the trained professional, providing visibility to nursing actions and supporting decision making(9). Corroborating this proposition, the use of software as an ally to care planning tends to help nurses to apply or modify clinical judgment, subsidize decision-making in the ND selection process, in addition to configuring a learning tool with the potential to expand the knowledge of professionals ${ }^{(19)}$.

As for the methodological rigor adopted for the construction of the educational software, it proved to be imperative for the result obtained in the evaluations. Integrative review ${ }^{(11)}$ showed urgency in the development of studies with this theme in order to replicate the research, therefore, many studies do not clearly outline their methodology.

Methodological research is carried out in order to develop a reliable, accurate and usable educational technology for nursing ${ }^{(3)}$. These have been considered a major challenge in terms of systematizing research for the construction, evaluation and validation of these types of technology ${ }^{(3)}$. The educational software, aimed at any discipline or target audience, must be subjected to an assessment that precedes its implementation in the educational context ${ }^{(20)}$. Thus, the software was approved by 39 students based on the "content", "usability" and "didactic" competencies, using a questionnaire with a conformity assessment scale.

The participating students were in the fifth semester of the nursing course, when the subject of ND was introduced. The software's approval by this audience corroborates the possibility of implementing the tool in nursing courses as a pedagogical strategy. The developed tool, as in another study on educational software, supports the use of mixed teaching strategies, being able to use combinations of traditional methods combined with technology, enhancing the learning resources ${ }^{(9)}$.

On average, $97 \%$ of students "completely agreed" or "agreed" on the content assessment. In assessing the usability of the software, about $95 \%$ of the students either "completely agreed" or "agreed" on this criterion. On average $84 \%$ of the students either "completely agreed" or "agreed" on the teaching methods used. Aspects of positive software evaluation were analyzed in equivalent studies ${ }^{(6,8)}$, supporting students' adherence and the relevance of this technology in the educational field. It should be noted that, in this last criterion, the question "Did you need help from literature to develop the steps?" was asked, resulting in $25.64 \%$ of the students answering both "completely agree" and "completely disagree". It is inferred that this result was dependent on the experience of each student with the NDs. Although academics could present different levels of contact with the NANDA-I taxonomy, researchers from the Federal University of Ceará identified that students had a moderate to good performance in the evaluation of educational software, and that this was not related to age, academic level or previous experience with NANDA-(9).

The software dismisses the use of literature for its applicability. However, as the assessment was carried out with students who are being introduced to this field of knowledge, it is permitted and pedagogically healthy to use didactic materials as an optional consultation. For nursing practice and teaching, the software allows for greater flexibility and individualization of the teaching-learning process, as it allows the teacher to edit/add new case studies, and to respect each individual's learning pace.

The limitations of the study are related to the restricted number of possible groupings for the student's reasoning, given the particularities of the screen size. We also highlight that the development technology has a high cost, which limited the expansion of the software to another more Web accessible language. The software developed was only tested at one university, so we suggest that it be tested in other realities in order to undergo adjustments for better performance.

\section{CONCLUSION}

The developed software can stimulate the diagnostic reasoning and promote the improvement of the accuracy of nursing students and nursing assistants. Through its development, it was possible to establish criteria and parameters for the Educational Software to be considered an interactive tool, capable of reducing barriers in the teaching-learning process.

The tool is available $\mathbf{l}^{\mathbf{1}}$ for the use of disciplines in the Nursing undergraduate course, in order to facilitate the teaching/learning of students in the elaboration of accurate NDs. In addition, the instrument is an accessible option for training newly admitted nurses in the fields of work that use computerized NP in clinical practice.

\footnotetext{
${ }^{1}$ Any university may have the software for use in teaching, as long as authorization is requested from the researchers.
} 


\section{REFERENCES}

1. Marin HF, Peres HHC. 0 ensino de informática em saúde e o curriculum de enfermagem [editorial]. J Health Inform. 2015 [cited 2019 0ct 4];7(4):I. Available from: http://www.jhi-sbis.saude.ws/ojs-jhi/index.php/jhi-sbis/ article/view/449/248

2. Schall Jr MC, Cullen L, Pennathur P, Chen H, Burrell K, Matthews G. Usability evaluation and implementation of a health information technology dashboard of evidence-based quality indicators. Comput Inform Nurs. 2017;35(6):281-8. doi: https://doi.org/10.1097/CIN.0000000000000325

3. Melo ECA, Enders BC, Basto ML. Plataforma PEnsinar ${ }^{\oplus}$ : a learning tool for teaching the nursing process. Rev Bras Enferm. 2018;71(Suppl 4):1522-30. doi: https://doi.org/10.1590/0034-7167-2016-0411

4. Jerônimo IRL, Campos JF, Peixoto MAP, Brandão MAG. Use of clinical simulation to improve diagnostic reasoning in nursing. Esc Anna Nery. 2018;22(3):e20170442. doi: https://doi.org/10.1590/2177-9465-ean-2017-0442

5. Camargo FC, Fonseca CCM, Pereira GA, Manzan WA, Nogueira Junior HB. Produção nacional sobre Softwares apoiadores da atuação de enfermeiros hospitalares. J Health Inform. 2018 [cited 2019 0ct 24];10(4):125-30. Available from: $\quad$ http://www.jhi-sbis.saude.ws/ojs-jhi/index.php/jhi-sbis/article/ view/584

6. Jensen R, Lopes MHBM, SilveiraPSP,Ortega NRS. The development and evaluation of software to verify diagnostic accuracy. Rev Esc Enferm USP. 2012;46(1):18491. doi: https://doi.org/10.1590/S0080-62342012000100025

7. Booth RG, Sinclair B, Brennan L, Strudwick G. Developing and implementing a simulated electronic medication administration record for undergraduate nursing education: using sociotechnical systems theory to inform practice and curricula. Comput Inform Nurs. 2017;35(3):131-9. doi: https://doi. org/10.1097/CIN.0000000000000309

8. Kowitlawakul Y, Chan MF, Tan SSL, Soong ASK, Chan SWC. Development of an e-learning research module using multimedia instruction approach. Comput Inform Nurs. 2017;35(3):158-68. doi: https://doi.org/10.1097/ CIN.0000000000000306

9. Sousa VEC, Lopes MVO, Keenan GM, Lopez KD. Developing and testing of a software prototype to support diagnostic reasoning of nursing students. Int J Nurs Knowl. 2018;29(2):124-32. doi: https://doi.org/10.1111/2047-3095.12145

\section{- Funding institution:}

Fundação de Apoio à Pesquisa do Rio Grande do Sul (FAPERGS) Edital PqG 06/2010 - Proceeding 1017319.

- Corresponding author:

Miriam de Abreu Almeida

E-mail: miriam.abreu2@gmail.com
10. Rabelo-Silva ER, Cavalcanti ACD, Caldas MCRG, Lucena AF, Almeida MA, Linch GFC, et al. Advanced nursing process quality: comparing the International Classification for Nursing Practice (ICNP) with the NANDA-International (NANDA-I) and Nursing Interventions Classification (NIC). J Clin Nurs. 2017;26(3-4):379-87. doi: https://doi.org/10.1111/jocn.13387

11. Moreira ACA, Teixeira FE, Araújo TL, Cavalcante TF, Silva MJ, Cruz ATCT. Software development for nursing care: integrative review. J Nurs UFPE online. 2016 [cited 2019 Sep 20];10(Suppl 6):4942-50. Available from: https://periodicos. ufpe.br/revistas/revistaenfermagem/article/view/11276/12918

12. Polit DF, Beck CT. Fundamentos de pesquisa em enfermagem: avaliação de evidências para a prática da enfermagem. Porto Alegre: Artmed; 2018.

13. Carlson J. Consensus validation process: a standardized research method to identify and link the relevant NANDA, NIC and NOC terms for local populations. Int J Nurs Terminol Classif. 2006;17(1):23-4. doi: https://doi. org/10.1111/j.1744-618X.2006.00020.x

14. Matos FGOA, Cruz DALM. Development of an instrument to evaluate diagnosis accuracy. Rev Esc Enferm USP. 2009;43(spe):1088-97. doi: https://doi. org/10.1590/50080-62342009000500013

15. Herdman TH, Kamitsuru S, organizadores. Diagnósticos de enfermagem da NANDA International: definições e classificações - 2018-2020. Porto Alegre: Artmed; 2018.

16. Pressman RS. Engenharia de software: uma abordagem profissional. Porto Alegre: McGraw-Hill-Bookman; 2011.

17. Instituto Nacional da Propriedade Industrial (BR). Certificado de Registro de Programa de Computador. Processo: BR 512014 001195-0. Software educativo do diagnóstico de Enfermagem. Rio de Janeiro: INPI; 2015.

18. Patel VL, Kannampallil TG, Kaufman DR, editors. Cognitive informatics for biomedicine: human computer interaction in healthcare. Cham: Springer; 2015 [cited 2019 Oct 5]. Available from: https://www.springer.com/us/ book/9783319172712

19. Lima JJ, Vieira LGD, Nunes MM. Computerized nursing process: development of a mobile technology for use with neonates. Rev Bras Enferm. 2018;71(Suppl 3):1273-80. doi: https://doi.org/10.1590/0034-7167-2017-0267

20. PereiraWS, Silva RST, Cardoso Filho RJ, SilvaWRA, AguiarYPC, DantasVF. Avaliação de software educativo: análise de abordagens para definição de diretrizes. In: Sánchez J, editor. Nuevas ideas en informática educativa. 2016;12:557-62.

\section{Associate editor:}

Cecília Helena Glanzner

Received: 11.01.2019

Approved: 08.19.2020
Editor-in-chief:

Maria da Graça Oliveira Crossetti 